\section{С.М. Потапов}

В.Д. Марковський

Д.І. Галата

О.М. Плітень

Н.І. Горголь

Харківський національний

медичний університет

Надійшла: 07.08.2019

Прийнята: 14.09.2019
DOI: https://doi.org/10.26641/1997-9665.2019.3.107-114

УДК: $616.681-006.6-091.8: 576.36$

\section{ІМУНОГІСТОХІМІЧНА ХАРАКТЕРИ- СТИКА ПРОЛІФЕРАТИВНО-АПОПТО- ТИЧНИХ ПРОЦЕСІВ В СЕМІНОМІ ЯЕЧКА}

Potapov S.M. (ID $₫$, Markovskyi V.D. (D), Galata D.I. (D), Pliten O.M. (D), Gorgol N.I. ID Immunohistochemical characteristic of proliferative and apoptotic processes in testicular seminoma.

Kharkiv National Medical University, Kharkiv, Ukraine

ABSTRACT. Background. Testicular tumors are rare neoplasia (1-2\% of all malignant tumors in men) and are more common in young men, what attaches importanceof this problem both medical and social significance. Objective. The aim of the work was to study proliferative and apoptotic processes in testicular seminoma. Methods. The study was performed on 13 surgically removed testicles affected by seminoma.Tumors were grouped according to the degree of tumorous progression in accordance with the pTNM classification. For evaluation of proliferative and apoptotic processes the relative area (S) and intensity (L) of Ki-67, Bax, Bcl-2, and p53 expression were studied. The proliferation index (PI) was calculated as well. Results. The study determined increasing of average S, L values of Ki-67 expression and PI, and also very high and moderate positive correlation between PI and $S$ with $L$ expression $(r=+0,98 ; r=+0,60 ; p<0,05$, respectively) during the transition from the initial to the late stages of tumorous progressionwas revealed. S of Bax expression was also increasing at the transition from early to late stages of tumorous progression, and L expression remained high regardless of stage. High positive correlation between $\mathrm{S}$ of Bax and $\mathrm{S}$ of Ki-67 expression and between $\mathrm{S}$ of $\mathrm{Bax}$ and PI $(\mathrm{r}=+0.83 ; \mathrm{r}=+0.84 ; \mathrm{p}<0.05$, respectively) was revealed during the transition from the initial to the late stages of tumorous progression. This result allows us to talk about the lack of resistance of seminoma tumorous cells to apoptosis. The activity of the anti-apoptotic protein bcl-2 in the seminoma was extremely insignificant, and p53 expression was absent, which together indicates a low tumor aggressiveness. Conclusion. Based on the foregoing we believe that in the diagnosis of testicular tumors it is appropriate to use Ki-67, Bax, bcl-2 and p53, as reflecting the malignant potential of the tumor and as prognostic markers. In the same time we have opinion that increasing of $\mathrm{S}$ of Bax expression during the transition from the initial to the late stages of tumorous progression in combination with 553 intactness characterizes seminoma as curable tumor with lowaggressiveness.

Key words: testicular seminoma, proliferative and apoptotic processes, immunohistochemical investigation.

\title{
Citation:
}

Potapov SM, Markovskyi VD, Galata DI, Pliten OM, Gorgol NI. [Immunohistochemical characteristic of proliferative and apoptotic processes in testicular seminoma]. Morphologia. 2019;13(3):107-14. Ukrainian.

DOI: https://doi.org/10.26641/1997-9665.2019.3.107-114

Potapov S.M. 0000-0002-5718-3341

Markovskyi V.D. 0000-0002-2237-3639

Galata D.I. 0000-0001-8850-8033

Pliten O.M. 0000-0001-6376-9376

iD Gorgol N.I. 0000-0003-2735-0310

凶pathomorphologist@gmail.com

(1) SI «Dnipropetrovsk Medical Academy of the Ministry of Health of Ukraine», «Morphologia»

\section{Вступ}

Пухлини яєчка відносяться до рідкісних новоутворень (1-2\% усіх злоякісних пухлин у чоловіків і 5\% пухлин сечостатевої системи) i частіше зустрічаються у молодих чоловіків (до $60 \%$ усіх новоутворень), що надає даній проблемі не тільки медичну, але і соціальну значимість [1,2].

Серед пухлин яєчка найбільш часто зустрічаються герміногенні пухлини, на частку яких припадає понад 90\% всіх пухлин яєчкаі найчастішою з них є семінома [3-6].

Наукові дані останніх десятиліть свідчать про доцільність використання маркерів біологічних властивостей для діагностики та диференційної діагностики пухлин різних локалізацій $[7,8]$. Однак, до теперішнього часу використання імуногістохімічних (ІГХ) методів для патоморфологічної оцінки герміногенних пухлин яєчок (ГПЯ) має вкрай обмежений харак- 
Tep.

Метою роботи було вивчення апоптотично-проліферативних процесів в семіномі яєчка.

\section{Матеріали та методи}

Дослідження виконано на матеріалі 13 видалених в ході орхіфунікулектоміі яєчок,уражених семіномою, а також історій хвороби на базі Харківського обласного клінічного центру урології і нефрології ім. В.І. Шаповала.

Всі дослідженні пухлини були розподілені згідно патологічної рTNM класифікації [9], що є вкрай важливим, тому що точне стадіювання у відповідності до сучасних уявлень $є$ фундаментальним [10].

Для найбільш наочного порівняння IГХ характеристик всі спостереження досліджених семіном були розділені за ступенем пухлинної прогресії.

Так, керуючись рTNM класифікацією, були сформовані наступні групи:

1. Група «1», при якій пухлина була обмежена яєчком і його придатком, без інвазії в кровоносні або лімфатичні судини; при цьому пухлина могла вростати в білкову, але не у вагінальну оболонку, а метастази у регіонарні лімфатичні вузли і віддалені метастази були відсутні; сироваткові пухлинні маркери мали різні значення. Пухлини даної групи відповідали стадіям $\mathrm{T}_{1} \mathrm{~N}_{0} \mathrm{~S}_{0-2}$.

2. Група «2», при якій пухлина була обмежена яєчком і його придатком 3 інвазією в кровоносні або лімфатичні судини, або пухлина проникала через білкову оболонку з ураженням вагінальної оболонки; при цьому були наявні метастази різного ступеня у регіонарні лімфатичні вузли, проте віддалені метастази були відсутні; сироваткові пухлинні маркери мали різні значення. Пухлини даної групи відповідали стадіям $\mathrm{T}_{2} \mathrm{~N}_{1-3} \mathrm{~S}_{0-2}$.

3. Група «3», при якій пухлина поширювалась на сім'яний канатик з/без інвазії в кровоносні або лімфатичні судини, при цьому, були наявні метастази різного ступеня у регіонарні лімфатичні вузли, а віддалені метастази були відсутні; сироваткові пухлинні маркери мали різні значення. Пухлини даної групи відповідали стадіям $\mathrm{T}_{3} \mathrm{~N}_{1-3} \mathrm{~S}_{0-2}$.

4. Група «4» характеризувалась наявністю у пацієнта віддалених метастазів. При цьому метастази у регіонарні лімфатичні вузли могли бути відсутні; сироваткові пухлинні маркери мали різні значення. Пухлини даної групи відповідали стадіям $\mathrm{T}_{2-3} \mathrm{~N}_{0-3} \mathrm{~S}_{0-2}$.

Матеріал для IГХ дослідження фіксували в 10\% нейтральному формаліні протягом 24 годин, заливали в парафін, готували зрізи товщиною $4 \times 10^{-6}$ м, які наносили на високоадгезивні скельця «SUPER FROST PLUS» фірми «DAKO» (Данія) і висушували при температурі $37^{\circ} \mathrm{C}$ протягом 18 годин. Демаскування було виконано методом кип'ятіння зрізів у цитратному буфері (pH 6,0). Для візуалізації первинних антитіл була застосована
UltraVisionQuantoDetectionSystems HRP Polymer («ThermoFisherScientificInc.», США). В якості хромогена використовували DAB (діамінобензидин). Зрізи дозабарвлювали гематоксиліном Майєра і заключали в канадський бальзам. Для кожного маркера 3 метою виключення хибнопозитивних або помилкових результатів були застосовані контрольні дослідження, в яких використовували зрізи 3 тканин, що рекомендовані виробником антитіл для позитивного контролю. Крім того, кожне дослідження мало негативний контроль без додавання первинних антитіл.

Для оцінки проліферативно-апоптотичних процесів досліджували експресію наступних ІГХ маркерів: Ki-67, Bax, Bcl-2 i p53.

Панель використаних при ІГХ досліджені первинних антитіл представлена в таблиці 1.

Таблиця 1

Панель первинних антитіл

\begin{tabular}{|c|c|c|}
\hline $\begin{array}{c}\text { Первинне } \\
\text { антитіло }\end{array}$ & Клон & Виробник \\
\hline $\begin{array}{l}\text { Mo a-Hu Ki-67 } \\
\text { Monoclonal Antibody }\end{array}$ & MIB-1 & $\begin{array}{l}\text { «DAKO», } \\
\text { Данія }\end{array}$ \\
\hline $\begin{array}{l}\mathrm{Rb} \text { a-HuBax } \\
\text { PolyclonalAntibody }\end{array}$ & & $\begin{array}{l}\text { «Thermo Fisher } \\
\text { Scientific Inc.», } \\
\text { США }\end{array}$ \\
\hline $\begin{array}{l}\text { Mo a-Hu Bcl-2 } \\
\text { Monoclonal Antibody }\end{array}$ & 100/D5 & $\begin{array}{l}\text { «Thermo Fisher } \\
\text { Scientific Inc.», } \\
\text { США }\end{array}$ \\
\hline $\begin{array}{l}\text { Mo a-Hu p53 } \\
\text { Monoclonal Antibody }\end{array}$ & DO-7 & $\begin{array}{l}\text { «AKO», } \\
\text { Данія }\end{array}$ \\
\hline
\end{tabular}

Для реалізації якісного та об'єктивного аналізу цифрових зображень була розроблена методика, яка дозволила 3 максимальною ефективністю проводити обробку зображень і отримувати більш точні та інформативні кількісні дані i, тим самим, поліпшити якість інтерпретації отриманих результатів [11].

Забарвлені зрізи досліджуваноїпухлинної тканини реєстрували за допомогою мікроскопу Olympus BX-41TF (Японія) і цифрової фотокамери Olympus C3040-ADU (Японія). Отримані фотографії обробляли у програмному пакеті Matlab, використовуючи стандартні інструменти обробки цифрових зображень. Для морфометричного вимірювання відносної площі (S), яку займають імунопозитивні структури, у виділеній області автоматично обчислювалось співвідношення кількості пікселів цифрового зображення області імунопозитивної реакції до загальної кількості пікселів в зображенні, визначене у \%. За значеннями яскравості колірних RGB каналів у кожному пікселі вихідного зображення розраховували допоміжні колірні координати CIE XYZ, а потім - колірні координати CIE Lab. Таким чином, вихідному цифровому зображенню від- 
повідав тримірний масив колірних координат CIE Lab, однією 3 яких є світлість/інтенсивність (L), значення котрої коливаються у межах від 0 до 100. При цьому, $\mathrm{L}=0-40$ відповідала сильному, $\mathrm{L}=40-50$ - середньому, а L=50-100 - слабкому рівню інтенсивності експресії маркера.Sта L експресії маркерів вивчалась у 10-30 випадково обраних полях зору мікроскопа Olympus BX-41TF при збільшенні $\times 200\left(3,12 \times 10^{-7} \mathrm{M}^{2}\right)$ у кожному спостереженні.

Проліферативна активність клітин семіноми була досліджена шляхом підрахунку відсотку імунопозитивно забарвлених клітин (з використанням моноклональних антитіл Мо а-Нu Ki-67, Clone MIB-1, «DAKO», Данія) в стандартизованому полі зору мікроскопа Olympus BX-41TF (Японія) на збільшенні $\times 400\left(7,5 \times 10^{-8} \mathrm{~m}^{2}\right) 3$ визначенням індексу проліферації (ІП). У кожному спостереженні аналізували по 20 полів зору 3 використанням наступної формули:

IП $=\frac{\text { кількість } \mathrm{Ki}-67-\text { імунопозитивних клітин }}{\text { загальна кількість клітин }} \times 100$

Рівень проліферації пухлинних клітин визначали за ядерною експресією Ki-67 [12]. Наявність $0-5 \%$ імунопозитивних клітин відповідало 0 балам (низький рівень проліферативної активності), 6-25\% - 1 балу (низький рівень проліферативної активності), 26$50 \%$ - 2 балам (помірний рівень проліферативної активності), 51-75\% клітин - 3 балам (помірний рівень проліферативної активності), 76-100\% - 4 балам (високий рівень проліферативної активності).

Статистична обробка отриманих данихздійснювалася за допомогою методів варіаційної статистики 3 використанням пакету статистичного аналізу тріал-версії STATISTICA 13.3 EN. Значимість відмінностей центральних тенденцій в групах, перевірялася при довірчій ймовірності 95\% (p<0,05). Для оцінки зв'язків між показниками використовували непараметричний коефіцієнт кореляції Спірмена [13].

Результати та їх обговорення

Отримані числові показники проліферативноапоптотичних процесів всеміномі представлені в таблиці 2.

Процесом, який відображає онкотрансформацію, злоякісність пухлинної тканини i прогресування пухлинного процесу, $\epsilon$ проліферація. Одним 3 найбільш специфічних маркерів проліферації є маркер Ki-67 [14].

Показники проліферативно-апоптотичних процесів в семіномі

Таблиця 2

\begin{tabular}{|c|c|c|c|c|c|}
\hline Показники & $\begin{array}{c}\text { Група «1» } \\
\left(\mathrm{n}_{1}=4\right)\end{array}$ & $\begin{array}{c}\text { Група «2» } \\
\left(\mathrm{n}_{2}=5\right)\end{array}$ & $\begin{array}{c}\text { Група «3» } \\
\left(\mathrm{n}_{3}=3\right)\end{array}$ & $\begin{array}{c}\text { Група «4» } \\
\left(\mathrm{n}_{4}=1\right)\end{array}$ & $\mathrm{p}$ \\
\hline $\mathrm{Ki}-67, \mathrm{~S}, \%$ & $1,17 \pm 0,07$ & $1,56 \pm 0,13$ & $1,91 \pm 0,05$ & $1,91 \pm 0,1$ & $\begin{aligned} \mathrm{p}_{12} & >0,05 \\
\mathrm{p}_{13} & =0,034 \\
\mathrm{p}_{23} & >0,05\end{aligned}$ \\
\hline Ki-67, L, од. & $43,02 \pm 0,36$ & $39,78 \pm 0,97$ & $37,52 \pm 0,3$ & $36,05 \pm 0,11$ & $\begin{aligned} \mathrm{p}_{12} & =0,016 \\
\mathrm{p}_{13} & =0,034 \\
\mathrm{p}_{23} & >0,05\end{aligned}$ \\
\hline ІІІ, \% & $19,3 \pm 0,75$ & $25,07 \pm 1,76$ & $29,87 \pm 1,36$ & $31,13 \pm 10,35$ & $\begin{aligned} \mathrm{p}_{12} & =0,032 \\
\mathrm{p}_{13} & =0,034 \\
\mathrm{p}_{23} & >0,05\end{aligned}$ \\
\hline Bax, S, \% & $2,74 \pm 0,1$ & $5,35 \pm 0,07$ & $6,0 \pm 0,06$ & $5,93 \pm 0,1$ & $\begin{array}{l}\mathrm{p}_{12}=0,016 \\
\mathrm{p}_{13}=0,034 \\
\mathrm{p}_{23}=0,025\end{array}$ \\
\hline Bax, L, од. & $37,46 \pm 0,13$ & $37,04 \pm 0,19$ & $36,39 \pm 0,21$ & $36,5 \pm 0,1$ & $\begin{aligned} \mathrm{p}_{12} & >0,05 \\
\mathrm{p}_{13} & =0,034 \\
\mathrm{p}_{23} & >0,05\end{aligned}$ \\
\hline Bcl-2, S, \% & - & - & - & - & - \\
\hline Bcl-2, L, од. & - & - & - & - & - \\
\hline $\mathrm{p}-53, \mathrm{~S}, \%$ & - & - & - & - & - \\
\hline p-53, L,од. & - & - & - & - & - \\
\hline
\end{tabular}

Також доведено, що індекс проліферації (IП) в пухлині служить незалежним прогностичним показником виникнення рецидиву, загальної та безрецидивної виживаності, а також передбачуваним чинником для визначення чутливості до хіміо- і променевої терапії [15].

В нашому досліджені були визначені відмінності середніх значень S експресії Кі-67 при переході від початкових до більш пізніх стадій пухлинної прогресії. Так, S експресії Кi-67 в групі «1» була невисокою, a L експресії - помірною. При цьому, експресія Кі-67 визначалась переважно в пухлинних клітинах, але була наявною і в клітинах імунного інфільтрату (рис. 1, А). 

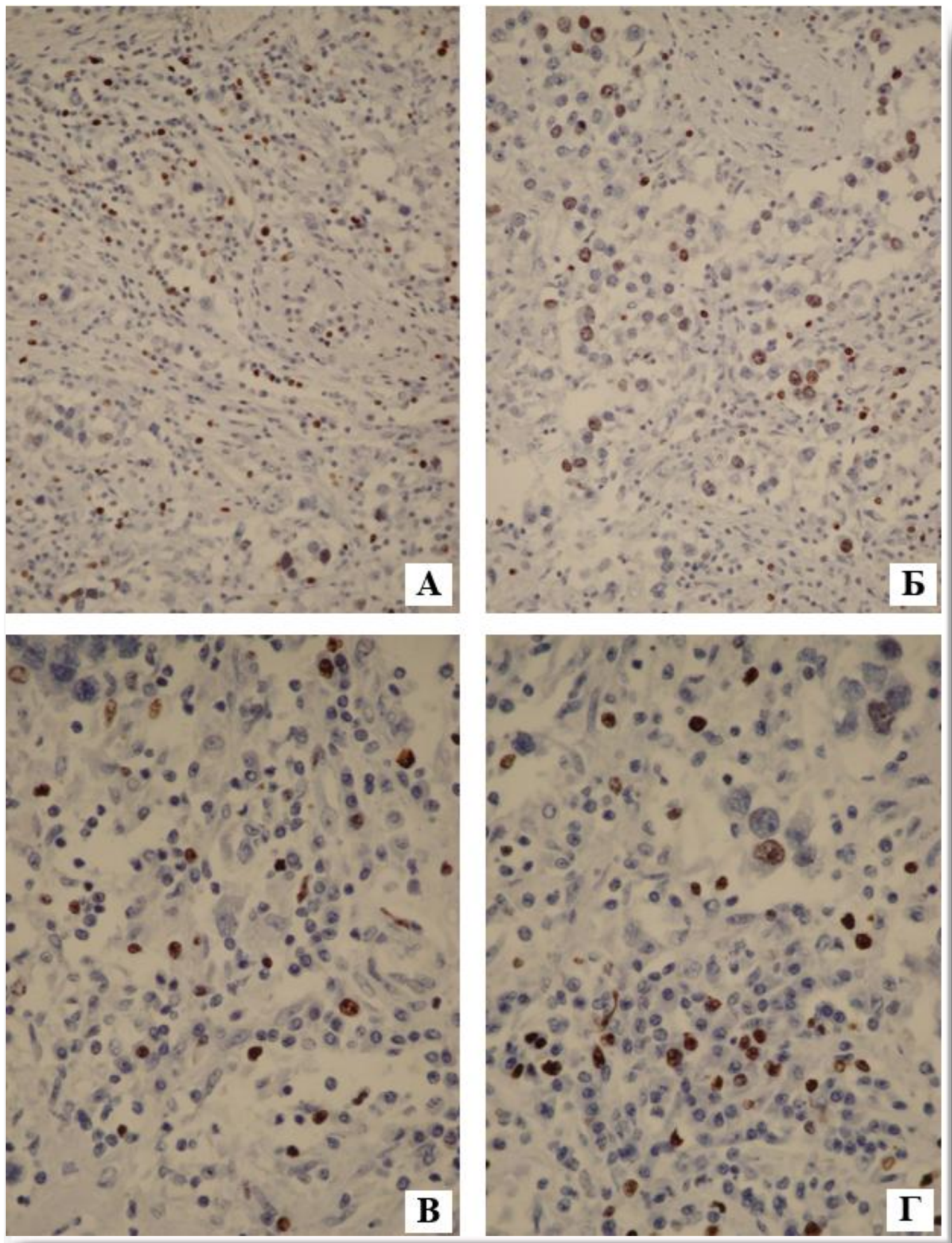

Рис. 1. А. Помірна інтрануклеарна реакція з Кі-67 в семіномі групи «1» (×200). Б. Помірна інтрануклеарна реакція з Кі-67 в семіномі групи «2» (×200). В. Інтенсивна інтрануклеарна реакція з Кi-67 в семіномі групи «3» (×400). Г. Інтенсивна інтрануклеарна реакція з Кі-67 в семіномі групи «4» (×400). ІГХ метод, додаткове забарвлення гематоксиліном Майєра.

ІП в групі «1» мав низький рівень і був найменшим 3 досліджених груп. В групі «2» $\mathrm{S}$ експресії Кі-67 достовірно не відрізнялась від такої в групі «1», на відміну від L експресії маркеру, яка зростала і була сильною. ІП в групі «2» був достовірно вищим за такий в групі «1» та наближався до помірного рівня.Як і в попередній групі,експресія Кі-67 відзначалась більшою мірою в пухлинних клітинах(рис. 1, Б). В групі «3» середня S експресії Ki-67 та його L були більшими за 
аналогічні показники в групі «1» і достовірно не відрізнялась від таких в групі «2». Така ж картина спостерігалась по відношенню до ІП: в групі «3» він був достовірно вищим за такий в групі «1» і не відрізнявся від аналогічного показника в групі «2», хоча і знаходився на помірному рівні. В єдиному випадку групи «4» Кi-67-позитивні клітини виявлялись або відносно рівномірно по всій площі пухлинної тканини, або нерівномірно, з посиленням в осередках більш вираженої атипії та інвазії (рис. 1, В, Г). Значення S експресії Кi-67, його L, a також ІП майже співпадали з відповідними значеннями групи «3».

Було встановлено, що по мірі зростання стадії пухлинної прогресії між IП та S і Lекспресії Кi-67 спостерігався дуже високий і помірний позитивний кореляційні зв'язки ( $r=+0,98 ; \mathrm{r}=+0,60 ; \mathrm{p}<0,05)$, що підтверджує ефективність використання вказаної методики у визначенні проліферативної активності.

В останні роки увагу багатьох дослідників притягнуто до вивчення апоптозу, який асоціюють 3 патогенезом багатьох захворювань, в тому числі онкологічних[16]. I якщо в здоровій тканині існує баланс між процесами проліферації і загибелі клітини, то в пухлинній тканині має місце автономна i необмежена проліферація клітин. При цьому в трансформованих клітинах виникає стійкість до індукції апоптозу [17].

В нашому дослідженні S експресії маркера апоптоза Вах в семіномі також характеризувалась зростанням по мірі збільшення стадії пухлинної прогресії. Середня S експресіїВах в групах «2» $\mathrm{i} « 3 »$ була вищою за таку в групі «1», де вона мала найменше значення. При цьому, S експресіїВах в групі «3» була більшою за аналогічний показник в групі «2». L експресії маркера залишалась високою незалежно від приналежності до тієї чи іншої групи, демонструючи достовірні відмінності в даному показнику лише між групами «1» i «3». В єдиному спостереженні групи «4» S експресії Bax та $\dddot{1}$ L майже співпадали 3 відповідними значеннями в групі «3». Експресія Вах визначалась в цитоплазмі пухлинних клітин і в одиничних клітинах пухлинного інфільтрату(рис. 2, А, Б).

При кореляційному аналізі було виявлено високий позитивний зв'язок між $\mathrm{S}$ експресії $\mathrm{Bax}$ та $\mathrm{S}$ експресіїKi-67 з ІІІ ( $\mathrm{r}=+0,83 ; \mathrm{r}=+0,84 ; \mathrm{p}<0,05$ відповідно)по мірі зростання стадії пухлинної прогресії. Це свідчить про підвищення рівня апоптозу по мірі зростання проліферативної активності та дозволяє говорити про відсутність стійкості пухлинних клітин в семіномі до апоптозу, який виступає інгібітором росту пухлини [18].

Маркер bcl-2 - ген, який кодує протеїн «виживання», відомий як інгібітор апоптозу. Коли bcl-2 гіперекспресує, він відіграє важливу роль в туморогенезі $[19,20]$. Також існують дані, що підвищена експресія bcl-2 корелює 3 кращим виживанням і асоціюється 3 низьким стадіюванням і градацією пухлин [20].

В нашому дослідженні маркер антиапоптоза bcl-2 виявлявся лише в одиничних пухлинах: в одному з п’яти спостережень групи «2», одному 3 трьох випадків групи «3» і в єдиному групи «4». При цьому позитивне забарвлення виявлялось лише в цитоплазмі поодиноких клітин імунного інфільтрата, а в пухлинних клітинах експресія bcl-2 виявлена не була (рис. 2, В, Г).

Таким чином, активність антиапоптотичного білка bcl-2 в семіномі була вкрай незначною, що опосередковано свідчить про іiі невисоку агресивність. А переважна локалізація bcl-2в клітинах імунного інфільтрату в окремих випадках говорить о збереженні захисної функції імунної системи.

Серед публікацій, присвячених вивченню прогностичного значення генів, які беруть участь в канцерогенезі,одним 3 найбільш вивчених генів-супресорів є p53, який регулює клітинний цикл і підтримку цілісності геному[21, 22].

Вважають, що мутації р53 можуть не тільки ініціювати канцерогенез i визначати його початкові етапи, але й виникати в процесі росту пухлини, що обумовлює іiї агресивні властивості. Мутантний p53 визначається при багатьох злоякісних новоутвореннях, таких як пухлини легенів, молочної залози, шлунку, яєчника, нирок $[21,23,24]$. В той же час нам зустрілося лише одне повідомлення, що ген-супресор р53 в ГПЯ буває мутований рідко [25].

В нашій роботі експресія р53 була відсутня в усіх спостереженнях групи «1» і в двох 3 п'яти випадків групи «2» (відповідно, в трьох, було відмічене позитивне забарвлення поодиноких пухлинних клітин). В групах «3» і «4» всі спостереження характеризувалися позитивною реакцією 3 p53, але лише в поодиноких пухлинних клітинах. Наведене свідчить про невисоку агресивність семіноми, оскільки інтактність р53 зазвичай $\epsilon$ характеристикою менш агресивних пухлин, чутливих до протипухлинної терапії [26].

\section{Підсумок}

Виходячи $з$ викладеного, вважаємо, що поряд 3 традиційними прогностичними факторами, такими як клінічні та гістологічні, в діагностиці пухлин яєчок доцільно використовувати маркери Ki-67 та p53, як такі, що відображають злоякісний потенціал пухлини та як прогностичні маркери. Водночас маємо думку, що збільшення Sекспресії маркера апоптоза Вах по мірі зростання пухлинної прогресії в поєднанні 3 інтактністю маркера р53, характеризує семіному, як менш агресивну і курабельну пухлину. 

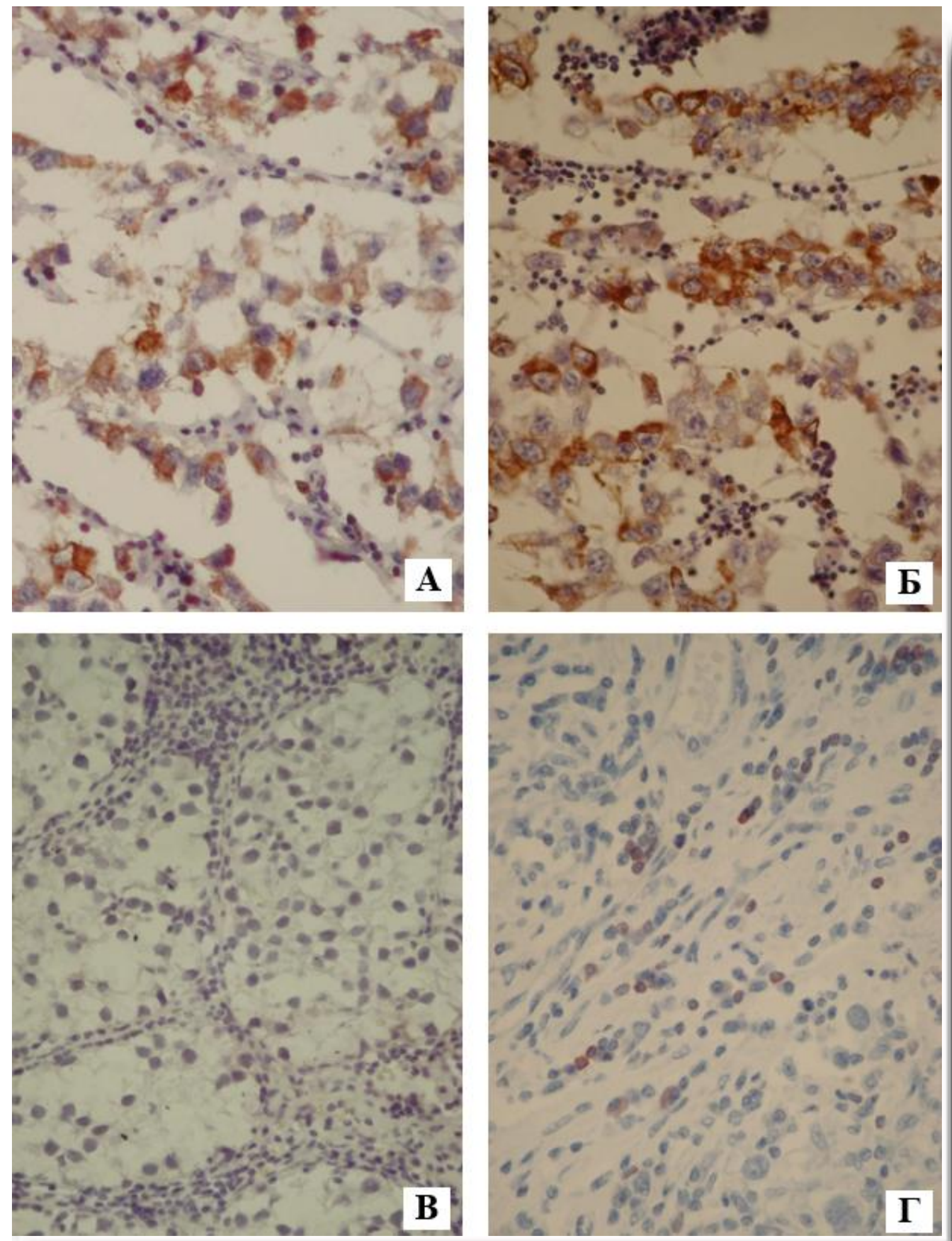

Рис. 2. А. Інтенсивна цитоплазматична реакція з Вах в семіномі групи «1» (×400). Б. Інтенсивна цитоплазматична реакція з Вах в семіномі групи «3» (×400). В. Негативна реакція з bcl-2 в семіномі групи «1» (×400). Г. Слабка реакція з bcl-2 в поодиноких клітинах імунного інфільтрату в семіномі групи «2» (×400). ІГХ метод, додаткове забарвлення гематоксиліном Майєра.

Перспективи подалыших досліджень полягають у продовженні вивчення проліферативноапоптотичних процесів в інших гістотипах ГПЯ.

Інформація про конфлікт інтересів

Потенційних або явних конфліктів інтересів, що пов'язані з цим рукописом, на момент публікації не існує та не передбачається.

\section{Джерела фінансування}

Дослідження проведено в рамках науководослідної теми «Вивчення значення молекуляр- 
но-біологічних маркерів для прогнозу, лікування і виживання хворих з основними локалізаціями раку» (номер державної реєстрації 0114U003394).

\section{Літературні джерела \\ References}

1. Loran OB, Bogdanov AB, Ivkin EV, Sokolov EA,MetelyovAYu. [Radical and testicularsparing surgery for testicular malignancy].Russian Journal of Surgery. 2014;1:25-30. Russian.

2. Nosov AK, Mamizhev EM, Vorobev AV, Zhukov OB, Novikov AI, Zassev RD, Korneev IA, Petrov SB. [Incidentalomas of the testicle and testicular microlithiasis: Current approaches to diagnosis and treatment (literaturereview, clinicalcases)]. Andrology and Genital Surgery. 2017;1:28-38. Russian.

3. Nemtsova MV, Ivkin EV, Tryakin AA, Rudenko VV, Dantsev IS, Tyulyandin SA, Loran OB.

[Geneticriskfactorsforsporadicgermcelltesticulartum ors]. Urologiia. 2017;1:24-30. Russian.

4. Mustafa SA, Mitla V, Banday SZ, Kuchay S. [ProfileofTesticularGermCellTumorsinKashmir: A RetrospectiveAnalysis]. International J. ofScientificStudy. 2017;5(4):183-186.

5. Vozianov OF, Romanenko AM, Klimenko IO. [Modern oncourology: achievements, problems, and outlooks]. Oncology. 2006;8(2):152-158. Ukrainian.

6. Stang A, Trabert B, Wentzensen N, Cook MB, Rusner C, Oosterhuis JW, McGlynn KA. Gonadal and extragonadal germ cell tumours in the United States, 1973-2007. Int J Androl. 2012 Aug;35(4):616-25. doi: 10.1111/j.13652605.2011.01245.x.Epub 2012 Feb 9. PubMed PMID: 22320869; PubMed Central PMCID: PMC3631107.

7. Klisho EV, Kondakova IV, Choinzonov EL, Cheremisina OV, ChizhevskayaSYu, Shishkin DA. [Prognostic significance of determination of matrix metalloproteinases and their tissue inhibitors of patients with head and neck squamous cell carcinoma]. Oncosurgery. 2011;3(1):17-22.Russian.

8. Shchurov NF. [Dependence of breast cancer metastasis to regional lymph nodes of the level of p53 expression in the tumor]. Oncology. 2014;16(3):203-205. Russian.

9. Moch H, Cubilla AL, Humphrey PA, Reuter VE, Ulbright TM. The 2016 WHO Classification of Tumours of the Urinary System and Male Genital Organs-Part A: Renal, Penile, and Testicular Tumours. Eur Urol. 2016 Jul;70(1):93-105. doi:10.1016/j.eururo.2016.02.029. Epub 2016 Feb 28. Review. PubMed PMID: 26935559.

10. Lobo J, Costa AL, Vilela-Salgueiro B, Rodrigues $\hat{A}$, Guimarães R, CantanteM,Lopes $\mathrm{P}$, Antunes L, Jerónimo C, Henrique R. Testicular germ cell tumors:revisiting a series in light of the new WHO classification and AJCC staging systems, focusing on challenges for pathologists. Hum Pathol.
2018

Dec;82:113-124.

doi: 10.1016/j.humpath.2018.07.016. Epub 2018 Jul 21. PubMed PMID: 30041024.

11. Potapov SM, Markovskiy VD, KulIshova $\mathrm{NE}$, invertors; Kharkiv national medical university. Method of quantitative estimation of lightness and relative area of markers expression atimmunohistochemicalinvestigation of tissues. Ukrainian patent UA119922. 2019Aug27.Int.Cl. G01N 21/00 (2006.01) G01N 21/62 (2006.01). Ukrainian.

12. Risberg B, Karlsson K, Abeler V, Lagrelius A, Davidson B, Karlsson MG. Dissociated expression of Bcl-2 and $\mathrm{Ki}-67$ in endometrial lesions: diagnostic and histogenetic implications. Int $\mathbf{J}$ GynecolPathol. 2002 Apr;21(2):155-60. PubMed PMID: 11917225.
13. Kobzar
AI,
author;

Prikladnayamatematicheskayastatistika.

Dlyainzhenerovinauchnyihrabotnikov. FIZMATLIT, 2012. 816 p. Russian.

14. Shatseva TA, Muhina MS. [Ki-67 antigen in the evaluation of tumor proliferation. Its structure and functions]. Problems in oncology. 20042:157163. Russian.

15. Pozharisskiy KM, Leenman EE. [Znachenieimmunogistohimicheskihmetodikdlyaopr edeleniyaharakteralecheniyaiprognozaopuholevyihz abolevaniy]. Archive of Pathology. 2000;5:3-11.

16. Paltsev MA. [Molecular medicine: achievements and perspectives]. Molecular medicine. 2004;4:3-12.

17. Rayhlin NT, Rayhlin AN. [Regulation and manifestation of apoptosis in physiological conditions and in tumors Problems in oncology]. 2002;48:157-163. Russian.

18. Fauvet R, Dufournet C, Poncelet C, Uzan C, Hugol D, Daraï E. Expression of pro-apoptotic (p53, p21, bax, bak and fas) and anti-apoptotic (bcl2 and bcl-x) proteins in serous versus mucinous borderline ovarian tumours. J SurgOncol. 2005Dec 15;92(4):337-43. PubMed PMID: 16299808.

19. Lee CT, Genega EM, Hutchinson B, Fearn PA, Kattan MW, Russo P, Reuter VE. Conventional (clear cell) renal carcinoma metastases have greater bcl-2 expression than high-risk primary tumors. UrolOncol. 2003 May-Jun;21(3):179-84. PubMed PMID: 12810203.

20. Itoi T, Yamana K, Bilim V, Takahashi K, Tomita $\mathrm{F}$. Impact of frequent $\mathrm{Bcl}-2$ expression on better prognosis in renal cell carcinoma patients. $\mathrm{Br}$ J Cancer. 2004 Jan 12;90(1):200-5. PubMed PMID: 14710230; PubMed Central PMCID: PMC2395310.

21. Zolota V, Tsamandas AC, Melachrinou M, Batistatou A, Scopa C. Expression of CD44 protein 
in renal cell carcinomas: association with p53 expression. UrolOncol. 2002 Jan-Feb;7(1):13-7. PubMed PMID: 12474536.

22. Kopnin BP. [Misheni deystviya onkogenov I opuholevyih supressorov: klyuch $\mathrm{k}$ ponimaniyu bazovyih mehanizmov kantserogeneza]. Biohimiya. 2000;65:5-33.

23. Soussi T, Dehouche K, Béroud C. p53 website and analysis of p53 gene mutations in human cancer: forging a link between epidemiology and carcinogenesis. Hum Mutat. 2000;15(1):105-13.

24. Pieretti M, Hopenhayn-Rich C, Khattar NH, Cao Y, Huang B, Tucker TC. Heterogeneity of ovarian cancer: relationships among histological group, stage of disease, tumor markers, patient characteristics, and survival. Cancer Invest. 2002;20(1):11-23. PubMed PMID: 11852993.

25. Jones RH, Vasey PA. New directions in testicular cancer; molecular determinants of oncogenesis and treatment success. Eur J Cancer. 2003 Jan;39(2):147-56. Review. PubMed PMID: 12509945.

26. Wu J, Guo A, Li Q, Wang D. Meta-analysis of clinical significance of $\mathrm{p} 53$ protein expression in patients with osteosarcoma. Future Oncol. 2017 Sep;13(21):1883-1891. doi: 10.2217/fon-2017-0180. Epub 2017 Aug 2. PubMed PMID:28766969.

Потапов С.М., Марковський В.Д., Галата Д.І., Плітень О.М., Горголь Н.І. Імуногістохімічна характеристика проліферативно-апоптотичних процесів в семіномі ясчка.

РЕФЕРАТ. Актуальність. Пухлини яєчка відносяться до рідких новоутворень (1-2\% усіх злоякісних пухлин у чоловіків) і частіше зустрічаються у молодих чоловіків, що надає проблемі як медичну, так і соціальну значимість. Метою роботи було вивчення проліферативно-апоптотичних процесів в семіномі яєчка. Методи. Дослідження виконано на матеріалі 13 оперативно видалених яєчок, уражених семіномою. Результати. В дослідженні визначено зростання середніх значень S, L експресії Кі-67 та IП, а також встановлений дуже високий і помірний позитивний кореляційні зв'язки між ІП та S i L експресії Ki-67 (r= +0,98; r= +0,60; p<0,05 відповідно) при переході від початкових до більш пізніх стадій пухлинної прогресії. S експресії Вах також зростала по мірі збільшення стадії пухлинної прогресії семіноми, a L експресії залишалась високою незалежно від стадії. При кореляційному аналізі виявлено високий позитивний зв'язок між $\mathrm{S}$ експресії Вax та $\mathrm{S}$ експресії $\mathrm{Ki}-67$ з IП (r= +0,83; r= +0,84; $<<0,05$ відповідно) по мірі зростання стадії пухлинної прогресії. Активність антиапоптотичного білка bcl-2 в семіномі була вкрай незначною, а експресія р53 - відсутня, що разом свідчить про невисоку агресивність пухлини. Підсумок. Виходячи з викладеного, вважаємо, що в діагностиці пухлин яєчок доцільно використовувати маркери Ki-67, Bax, bcl-2 i p53, як такі, що відображають злоякісний потенціал пухлини, та як прогностичні маркери. Водночас маємо думку, що збільшення $\mathrm{S}$ експресії маркера апоптоза Вах по мірі зростання пухлинної прогресії в поєднанні з інтактністю маркера р53, характеризує семіному, як менш агресивну і курабельну пухлину.

Ключові слова: семінома яєчка, проліферативно-апоптотичні процеси, імуногістохімічне дослідження.

Потапов С.Н., Марковский В.Д., Галата Д.И., Плитень О.Н., Горголь Н.И. Иммуногистохимическая характеристика пролиферативно-апоптотических процессов в семиноме яичка.

РЕФЕРАТ. Актуальность. Опухоли яичка относятся к редким новообразованиям (1-2\% всех злокачественных опухолей у мужчин) и чаще встречаются у молодых мужчин, что придает проблеме как медицинскую, так и социальную значимость. Целью работы было изучение пролиферативно- апоптотических процессов в семиноме яичка. Методы. Исследование выполнено на материале 13 оперативно удаленных яичек, пораженных семиномой. Результаты. В исследовании определены рост средних значений S, L экспрессии Ki-67 и ИП, а также установлены очень высокая и умеренная положительные корреляционные связи между ИП и $\mathrm{S}$ c L експресії ( $\mathrm{r}=+0,98 ; \mathrm{r}=+0,60 ; \mathrm{p}<0,05$ соответственно) при переходе от начальных к более поздним стадиям опухолевой прогрессии. $\mathrm{S}$ экспрессии Вах также возрастала по мере увеличения стадии опухолевой прогрессии семиномы, a L экспрессии оставалась высокой независимо от стадии. При корреляционном анализе выявлена высокая положительная связь между $\mathrm{S}$ экспрессии Вах и $\mathrm{S}$ экспрессии Кi-67 с ИП ( $\mathrm{r}=+0,83$; $\mathrm{r}=+0,84$; $\mathrm{p}<0,05$ соответственно) по мере роста стадии опухолевой прогрессии. Активность антиапоптотического белка bcl-2 в семиноме была крайне незначительной, а экспрессия р53 - отсутствовала, что вместе свидетельствует о невысокой агрессивности опухоли. Выводы. Исходя из изложенного, считаем, что в диагностике опухолей яичек целесообразно использовать маркеры Ki-67, Bax, bcl-2 и p53, как отражающие злокачественный потенциал опухоли, и как прогностические маркеры.В то же время имеем мнение, что увеличение $\mathrm{S}$ экспрессии маркера апоптоза Вах по мере роста опухолевой прогрессии в сочетании с интактностью маркера р53, характеризует семиному, как менее агрессивную и курабельную опухоль.

Ключевые слова: семинома яичка, пролиферативно-апоптотические процессы, иммуногистохимическое исследование. 